И. М. Дашанимаева. Анализ факторов риска сердечно-сосудистых заболеваний у пожилых пациентов

УДК $616.1-613.6 .01$

DOI: 10.18101/2306-1995-2019-2-33-37

\title{
АНАЛИЗ ФАКТОРОВ РИСКА СЕРДЕЧНО-СОСУДИСТЫХ ЗАБОЛЕВАНИЙ У ПОЖИЛЫХ ПАЦИЕНТОВ
}

\author{
(c) Дашанимаева Ирина Михайловна \\ кандидат медицинских наук, \\ старший преподаватель, Медицинский институт, \\ Бурятский государственный университет им. Д. Банзарова \\ Россия, 670000, г. Улан-Удэ, ул. Октябрьская, 36а \\ E-mail: : tspasova@inbox.ru \\ В статье представлены результаты изучения факторов риска сердечно- \\ сосудистых заболеваний при проведении анкетирования в доме-интернате для \\ пожилых граждан и инвалидов. \\ Ключевые слова: факторы риска, артериальная гипертония, курение, \\ злоупотребление алкоголя, наследственность, физическая активность, сердечно- \\ сосудистые заболевания \\ Для цитирования: \\ Дашанимаева И. М. Анализ факторов риска сердечно-сосудистых заболеваний у \\ пожилых пациентов // Вестник Бурятского государственного университета. \\ Медицина и фармация. 2019. Вып. 2. С. 33-37.
}

В настоящее время во всем мире отмечается увеличение доли населения пожилого возраста, сейчас в мире более 380 млн человек в возрасте старше 65 лет, в России это 1/5 часть населения. Уровень заболеваемости увеличивается с возрастом, у пожилых людей он выше в 2 раза, по сравнению с показателями у молодых лиц, в старческом возрасте - в 6 раз $[1,2]$.

С возрастом изменяется у человека социально-психологический статус, которому способствуют такие факты как выход на пенсию, смерть близких и друзей, одиночество и ограничение жизнедеятельности, трудность общения, снижение уровня жизни, смена жительства.

С ростом продолжительности жизни врачи все чаще имеют дело с сердечно-сосудистыми болезнями пожилых людей. На территории обслуживания городской поликлиники № 3 находится Улан-Удэнский комплексный центр социального обслуживания населения «Доверие», где проживает около 300 жильцов, в большинстве своем лица пожилого возраста.

Цель: выявить факторы риска сердечно-сосудистых заболеваний у населения Улан-Удэнского комплексного центра социального обслуживания населения «Доверие». 


\section{Материал и методы исследования}

В июле 2019 г. проведено независимое анкетирование жильцов Улан-Удэнского комплексного центра социального обслуживания населения «Доверие» студентами 5 курса медицинского института БГУ.

В анкетировании приняли участие 175 человек, из которых 91 мужчина и 84 женщин.

По возрасту респонденты распределились следующим образом: возрасте 30-39 лет - 3 ч $(1,6 \%)$, в возрасте 40-49 лет - 5ч. $(2,9 \%)$, в возрасте 50-59 лет - 18 ч (10,3\%), в возрасте $60-69$ лет - 57 ч $(32,6 \%)$, в возрасте $70-79 л е т-45$ ч $(25,7 \%)$, в возрасте 80 лет и старше - 47 ч (26,9\%).

\section{Результаты исследования и обсуждение}

Согласно исследованиям ВОЗ, значительно повышают риск внезапной смерти три основных фактора: гипертония, гиперхолестеринемия и курение.

По результатам анкетирования установлено, что 44 респондента курят, что составляет $25,1 \%$, остальные 131 - не курят. Более, чем у половины опрошенных поднимается артериальное давление свыше 140/90 мм рт. ст.

Генетические факторы, предрасполагающие к инфаркту миокарда и мозговому инсульту, наблюдаются примерно у 25\% людей в мире. Эти факторы обуславливают появление врожденного дефекта артерий, даже несмотря на соблюдение здорового образа жизни и отсутствие факторов риска возникновения сердечно-сосудистых заболеваний.

На вопрос «Болели Ваши близкие родственники сердечнососудистыми заболеваниями?» - 58,8\% отметили наличие у родственников артериальной гипертензии, у $36 \%$ респондентов родственники перенесли инфаркт миокарда, а в $16,6 \%$ отмечен в анамнезе перенесенный инсульт.

Выяснено: у 85,1\% опрошенных бывают головные боли; $62,8 \%$ беспокоит головокружение; у $37,1 \%$ - встречается шаткость походки; у четверти $(26,8 \%)$ - боли в грудной клетке; у трети $(32,6 \%)-$ сердцебиение; 44\% отмечают тяжесть в ногах и $31,4 \%$ - отеки на ногах; 16,6\% отмечают онемение кончиков пальцев на ногах; 28\% вынуждены останавливаться при ходьбе.

К модифицируемым факторам риска смерти от сердечно-сосудистой патологии кроме артериальной гипертонии, сахарного диабета, избыточного веса, низкой физической активности, стресса и курения, относится и употребление алкоголя в опасных дозах. Безопасными дозами алкоголя в отношении развития сердечно-сосудистых осложнений ВО3 определила в перерасчёте на чистый этиловый спирт для мужчин менее 30 г, для женщин менее 15 г в сутки. Это составляет 25-30 мл водки, 100-125 
мл сухого вина или 250-300 мл пива для женщин, и 50-60 мл водки, 200250 мл сухого вина или 500-600 мл пива для мужчин.

В ходе анкетирования выявлено: в Улан-Удэнском комплексном центре социального обслуживания населения «Доверие» не употребляют алкоголь большинство респондентов 74,8\%, употребляют алкоголь 1 раз в неделю по выходным - 5,7\%, отметили употребление до 2 раз в месяц 18,3\%. Необходимо проводить разъяснительную профилактическую работу с пятой частью респондентов о вреде алкоголя на здоровье.

По результатам опроса отмечена подверженность стрессам большинству анкетируемых жильцов: беспокойство отмечают 53ч $(30,3 \%)$; бессонницей страдают - $113-(64,6 \%) ;$ реагируют отрицательно на резкие звук и свет сигналы 40 ч $(22,8 \%)$; перепады настроения встречаются у $60-(34,3 \%)$; трудно сосредоточиться 32 респондентам - $(18,3 \%)$; отмечают у себя апатию $75-(42,9 \%)$ респондентов.

Низкая физическая активность жильцов обусловлена состоянием здоровья в пожилом возрасте. На вопрос «Часто ли Вам приходится ходить пешком?» только 20 ч $(11,4 \%)$ отметили, что ежедневно проходят от 1,5 до 3 км. Основная масса опрошенных жильцов - 100 ч $(57,1 \%)$ проходят 1,5-3 км в неделю. Менее 1,5-3 км в неделю преодолевают 50 респондентов, что составляет $28,5 \%$.

Суммарный риск смерти от СС3 в течение 10 лет определяется по шкале SCORE (Systematic COronary Risk Evaluation), в зависимости от пола, возраста, курения, уровня систолического артериального давления и общего холестерина в сыворотке крови обследуемого. Суммарный риск считается высоким, если он составляет $\geq 5 \%[1,2]$.

По результатам проведенного анкетирования в $11,7 \%$ случаев выявлен высокий риск смерти от сердечно-сосудистых заболеваний, и в таком проценте случаев - отсутствие этого риска. У каждого четвертого - выраженный риск, у половины респондентов умеренная опасность сердечно-сосудистых заболеваний.

Устранение модифицируемых факторов риска, своевременное посещение врача, постоянный прием необходимых лекарственных препаратов, позитивное отношение к своему здоровью будут способствовать улучшению качества жизни пациентов. Результаты анкетирования необходимо использовать в планировании лечебнопрофилактических мероприятий медицинских и социальных работников учреждения. После возникновения признаков ишемической болезни сердца факторы риска способствуют прогрессированию развития заболевания. Поэтому одним из этапов лечения является коррекция факторов риска. 


\section{Заключение}

По данным исследования выявлена высокая частота факторов риска сердечно-сосудистых осложнений у обследуемых, а также высокая частота симптомов, указывающих на возможность наличия у них не диагностированных заболеваний, а именно: артериальной гипертензии, ишемической болезни сердца, хронической сердечной недостаточности. Эти пациенты нуждаются в своевременном обследовании, а также в коррекции факторов риска и надлежащей терапии.

\section{Литература}

1. Европейские рекомендации по профилактике сердечно-сосудистых заболеваний в клинической практике (пересмотр 2016) // Российский кардиологический журнал. 2017. № 6(146). С. 7-85.

2. Кардиоваскулярная профилактика 2017. Российские национальные рекомендации / под ред. С. А. Бойцова // Российский кардиологический журнал. 2018. № 23(6). С. 7-122. 
И. М. Дашанимаева. Анализ факторов риска сердечно-сосудистых заболеваний у пожилых пациентов

ANALYSIS OF CARDIAC DISEASE RISK FACTORS

IN ELDERLY PATIENTS

Irina M. Dashanimaeva

Candidate of medical sciences,

Senior Lecturer of Medical Institute,

Medical Institute, Dorzhi Banzarov Buryat State University

36a, Oktyabrskaya st., Ulan-Ude, 670001, Russia

E-mail: tspasova@inbox.ru

The article examined the risk factors of cardiac disease during a survey in a boarding house for senior citizens and people with disabilities.

Keywords: risk factors, arterial hypertension, smoking, alcohol abuse, heredity, physical activity, cardiological diseases. 